\title{
Anti-inflammatory Activities of Taxifolin from Opuntia humifusa in Lipopolysaccharide Stimulated RAW 264.7 Murine Macrophages
}

\author{
Jaeyoung Kim $\cdot$ Yonghwa Lee $\cdot$ Hyeon-jin An $\cdot$ Jae-duk Lee $\cdot$ Yongsub Yi* D

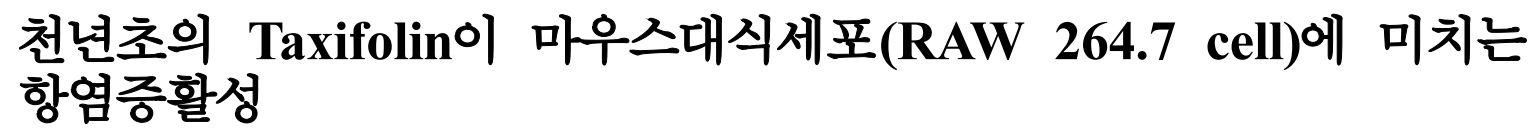

김재영 · 이용화 · 안현진 · 이재덕 · 이용섭*

Received: 28 May 2015 / Accepted: 26 June 2015 / Published Online: 30 September 2015

(C) The Korean Society for Applied Biological Chemistry 2015

\begin{abstract}
This study was performed to investigate the antiinflammatory activities of taxifolin from Opuntia humifusa. A potent anti-oxidant activity was shown from the leaf extract at $\mathrm{IC}_{50}$ value of $38.33 \pm 1.07 \mu \mathrm{g} / \mathrm{mL}$ and fruit extract at $\mathrm{IC}_{50}$ value of $40.23 \pm 2.21 \mu \mathrm{g} / \mathrm{mL}$ by 1,1-diphenyl-2-picrylhydrazyl assay. Fraction of taxifolin from leaf extract identified using high performance liquid chromatography and gas chromatography/mass spectrometry. The results of cell viability indicated that taxifolin did not show cytotoxicity on RAW 264.7 cells at $500 \mu \mathrm{M}$ of concentration. The result showed that taxifolin inhibited lipopolysaccharide (LPS)induced production of Nitrite oxide. In addition, taxifolin inhibited LPS-induced tumor necrosis factor- $\alpha$ and interleukin- 6 production by cytokine assay and cyclooxygenase- 2 expression by western blot analysis, meaning taxifolin has a significant anti-inflammatory effect. Our results suggested that taxifolin from Opuntia humifusa showed anti-inflammatory activities.
\end{abstract}

Keywords anti-inflammatory $\cdot$ cyclooxygenase- $2 \cdot$ cytotoxicity $\cdot$ interleukin-6 $\cdot$ Opuntia humifusa $\cdot$ taxifolin

J. Kim $\cdot$ Y. Lee $\cdot$ Y. Yi

Department of Herbal Cosmetic Science, Hoseo University, Asan 336-795, Republic of Korea

H.-J. An·J.-D. Lee

Yeo Myung Biochem Co., Ltd., Cheongwon-gun, Chungbuk, Republic of Korea

*Corresponding author (Y. Yi: yongsub@hoseo.edu)

This is an Open Access article distributed under the terms of the Creative Commons Attribution Non-Commercial License (http://creativecommons. org/licenses/by-nc/3.0/) which permits unrestricted non-commercial use, distribution, and reproduction in any medium, provided the original work is properly cited.
서 론

염증반응은 외부의 물리적, 화학적 자극, 세균에 의한 침윤작용 에 대한 면역체계반응의 하나이며 손상을 수복, 재생하려는 기 전이다(Zamora 등, 2000). 그러나 만성염증반응은 오히려 인간 에게 질병을 일으키는 원인이 되기도 한다. 염증반응에 의하여 활성화된 대식세포에서는 염증반응 시 발생하는 nitric oxide (NO) 와 tumor necrosis factor- $\alpha$ (TNF- $\alpha$ ), inerleukin-6 (IL-6) 등의 cytokine을 생산하여 초기 염증반응의 중요한 역할을 한다. 하 지만 과량 생성된 $\mathrm{NO}$ 는 급성과민성염증반응을 유도하는 무기 자유라디칼 물질로서 작용한다(Salerno 등, 2002; Libby, 2006). 염증인자들은 염증성장질환을 일으키며 심지어 암과 같은 만성 질환을 유발하기도 한다(Atreya 등, 2005). 따라서 염증인자를 제어하고 조절하는 것은 염증으로 인해 발생되는 만성염증질환 의 치료에 유용할 것으로 사료된다.

천년초(Opuntia humifusa)는 선인장과 식물로 열매가 달린 것 은 손바닥 선인장(Opuntiaficus-indicavar. Saboten Makin) 이라 불리며 선인장과(Cactaceae)에 속하는 열대성 식물로서 우리나 라에 자생하는 'Opuntia'속 중 내륙에서 $-20^{\circ} \mathrm{C}$ 에서도 생존하는 다년생 선인장을 천년초 선인장으로 부르고 있다(Carmen, 2000; Yoon과 Son, 2009).

천년초 추출물에서 특히 라디칼 소거능을 비롯한 강력한 항 산화 활성과 더불어 항균 효과를 보여주었으며 taxifolin과 같은 플라보노이드 화합물이 분포하는 것으로 보고 되었다(Lee 등, 2000; Lee 등, 2005; Lee와 Lee, 2010). 특히 taxifolin의 항산 화 효과가 $\alpha$-tocopherol보다 우수하다고 보고 되었으며(Lee, 2004), 1,1-diphenyl-2-picrylhydrazyl (DPPH) 라디칼에 대한 소 거활성 및 tyrosinase의 저해활성을 나타내어 화장품 첨가제로 서의 가능성을 시사하였다(Lee 등, 2000). 또한 천년초 추출물 이 3T3-L1 지방세포의 분화를 억제하고 지방축적과 관련된 PPAT $\gamma$ 및 adipocyte protein2의 mRNA의 발현을 억제하여 항 
비만 활성을 나타낸다고 보고 되었다(Kim 등, 2011). 따라서 본 연구에서는 천년초에서 추출 분리한 taxifolin이 Lipopolysaccharide (LPS) 에 의해 염증반응이 유도된 대식세포에서 염증작용 및 생리활성에 어떠한 영향을 미치는지를 알아 보고자 하였다.

\section{재료 및 방법}

실험재료. 본 실험에 사용된 천년초(Opuntia humifusa)는 충청 남도 아산에서 재배된 것으로 (주)패션푸드(Korea)에서 잎과 열 매가 분리된 건조분말형태로 구매하여 사용하였다.

시약 및 기기. 추출 및 분석을 위해 사용되는 용매는 모두 J.T. baker (USA) 사의 high performance liquid chromatography (HPLC)용 제품을 사용하였으며 천년초로 부터 taxifolin을 분리 하기 위하여 사용된 HPLC는 Varian사(USA)의 Pro Star system 으로 Prostar 230 pump와 Pro Star 410 auto sampler $(10 \mu \mathrm{L}$ sample loop)를 통하여 연결되었고 HPLC에서 얻은 chromatography는 $\mathrm{PC}$ 에 연결된 STAR STATION (Version 6.41)과 Pro Star 335 Photodiode array detector를 사용하여 분석하였다. 분석용 컬럼 은 Varian사의 Polaris 5 C18-A $250 \times 4.6 \mathrm{~mm}$ 를 사용하였다. 분 리된 taxifolin 분획만을 얻기 위해 fraction collector 701 module을 이용하였다.

세포배양으로 Dulbecco's Modified Eagle Medium, fetal bovine serum (FBS), Streptomycin-penicillin 등 세포배양용 시 약은 모두 Hyclone (USA) 제품을 사용하였다. 또한 실험에 사 용된 1차 항체인 $\beta$-actin monoclonal antibody와 cyclooxygenase (COX)-2는 Cell signalling technology (USA)에서 구입하였다. Cytokine assay를 위한 시약은 Koma biotech (Korea) 제품을 사용하였다. Taxifolin 표준품으로는 Sigma Co. (USA)의 제품 을 사용하였다. 그리고 실험에 사용된 모든 시약은 특급시약을 사용하였다.

Taxifolin 추출. 천년초는 잎과 열매형태로 구분되어 있으며 각 각 열매와 잎의 분쇄된 천년초가루 $50 \mathrm{~g}$ 를 메탄올 $500 \mathrm{~mL}$ 를 이 용하여 교반하여 상온에서 24시간 동안 추출하였다. 이와 같은 과정을 2 회 반복해준 뒤 $n$-Hexane 용매를 이용하여 수층만을 분리하여 실험에 사용하였다. 분리된 수층을 감압농축한 여액은 HPLC를 이용하여 taxifolin을 분리하였다. 분리조건은 Table 1 에 나타내었으며 분석용 컬럼은 Polaris $5(250 \times 4.6 \mathrm{~mm}, 180 \AA$, C18-A, Varian) 을 사용였다. Taxifolin의 분리는 표준품을 미리 분석하고 동일한 시간대에서 용출되는 분획을 fraction collector 를 이용하여 분리하였다. 표준품은 taxifolin (Sigma Co.)을 1 $\mathrm{mM}$ 의 농도가 되도록 methanol로 희석한 것을 표준액으로 하 였다.

DPPH 라디칼 소거능측정. 천년초의 항산화효과를 측정하기 위 하여 DPPH 라디칼을 이용하여 측정하였다(Blois, 1958). 천년 초는 잎과 열매로 구성되어 있으며 이 중 더욱 효과가 좋은 부 분을 확인하기 위하여 나누어 측정하였다. 측정방법은 $0.1 \mathrm{~mL}$ 의 taxifolin을 다양한 농도로 준비하여 여기에 $2.5 \mathrm{~mL}$ 의 에탄 올을 혼합하였다. 다시 $0.2 \mathrm{mM}$ 의 $\mathrm{DPPH}$ 용액을 $0.5 \mathrm{~mL}$ 를 첨가 하여 암실에서 1시간 동안 반응시켜 주었다. 반응 후 흡광광도 계를 이용하여 $517 \mathrm{~nm}$ (Benchmark Plus, Bio-Rad, USA)에서 흡광도를 측정하였다. 모든 실험은 3 회 반복 실험하였으며 대 조군으로 ascorbic acid를 사용하였고 공시료는 메탄올을 사용 하였다. $\mathrm{DPPH}$ 라디칼 소거능은 $50 \%$ 를 저해하는 $\mathrm{IC}_{50}$ 값으로 전
Table 1 Analytical conditions of HPLC for a taxifolin in Opuntia humifusa extract

\begin{tabular}{|c|c|c|c|}
\hline Instrument & Condition & & \\
\hline Column & $250 \times 4.6 \mathrm{~mm}$, & $180 \AA, \mathrm{C} 18-\mathrm{A}$, Varian & \\
\hline \multirow{12}{*}{ Mobile phase } & \multirow{2}{*}{ Time } & A & B \\
\hline & & $1 \%$ acetic acid in $\mathrm{H}_{2} \mathrm{O}$ & Acetonitrile \\
\hline & Initial & 99 & 1 \\
\hline & $4: 30$ & 97 & 3 \\
\hline & $6: 00$ & 96 & 4 \\
\hline & $7: 30$ & 93 & 7 \\
\hline & $13: 00$ & 86 & 14 \\
\hline & $14: 00$ & 85 & 15 \\
\hline & 19:00 & 76 & 24 \\
\hline & $24: 00$ & 60 & 40 \\
\hline & $34: 00$ & 60 & 40 \\
\hline & 40:00 & 99 & 1 \\
\hline Detector & \multicolumn{3}{|c|}{ PDA detector, $280 \mathrm{~nm}$} \\
\hline Flow rate & \multicolumn{3}{|l|}{$0.8 \mathrm{~mL} / \mathrm{min}$} \\
\hline Injection volume & \multicolumn{3}{|l|}{$10 \mu \mathrm{L}$} \\
\hline
\end{tabular}

환하여 나타내었다.

DPPH radical scavenging activity was calculated as follows:

$$
\text { Scavenging effect }(\%)=(\mathrm{A}-\mathrm{B}) / \mathrm{A} \times 100
$$

where $A=$ absorbance at $517 \mathrm{~nm}$ without test sample where $\mathrm{B}=$ absorbance at $517 \mathrm{~nm}$ with test sample 세포배양. 마우스의 대식세포(RAW 264.7, mouse macrophage) 는 한국세포주은행(Korean Cell Line Bank)에서 구입하였으며, 이 세포를 $37^{\circ} \mathrm{C}, 5 \% \mathrm{CO}_{2}$ 의 조건에서 $10 \% \mathrm{FBS}, 50 \mathrm{units} / \mathrm{mL}$ 의 streptomycin, $100 \mathrm{U} / \mathrm{mL}$ 의 penicillin (Hyclone, USA)을 첨 가하고 Dulbecco's Modified Eagle Medium (Hyclone)에서 배 양하였다.

MTT assay. 세포 독성시험을 통해 천년초에서 추출한 taxifolin 의 안정성을 평가하였다. 3-(4,5-Dimethylthiazol-2-yl)-2,5-Diphenyltetrazolium Bromide (MTT, Sigma Co.) assay로 측정하였다. 세포를 96-well plate의 각 well에 $1 \times 10^{5}$ cells/well의 농도로 분주한 다음 24 시간 동안 배양하고 taxifolin을 $1 \mu \mathrm{M}$ 에서 500 $\mu \mathrm{M}$ 까지 농도 별로 처리하였다. 다시 24시간 동안 배양한 후 Phosphate Buffered Saline (PBS)로 세척해주고 MTT를 $5 \mathrm{mg}$ / $\mathrm{mL}$ 농도가 되도록 $\mathrm{PBS}$ 에 녹여주고 새 배양액에 $500 \mu \mathrm{g} / \mu \mathrm{L}$ 이 되 도록 희석하여 각 well에 $100 \mu \mathrm{L}$ 씩 분주한 후 4시간 동안 배양 하였다. 배양이 끝난 후 dimethyl sulfoxide와 ethanol를 1:1 비 율이 되도록 섞어준 용액을 $150 \mu \mathrm{L}$ 씩 각 well에 분주하고 교반 용해시킨 후 $550 \mathrm{~nm}$ (Benchmark Plus, Bio-Rad)에서 각 well 의 흡광도를 측정하였다. 모든 실험은 세 번 반복 실험하였다. Cytokine assay. 세포 배양액 내의 cytokine의 양을 측정하기 위하여 Enzyme Linked Immunospecific Assay (ELISA, Komabiotech) 를 이용하였다. 세포를 96 well plate의 각 well에 $1 \times 10^{5}$ cells/ well의 농도로 분주한 다음 24 시간 동안 배양하였다. 배양된 세 포에 $\mathrm{LPS}$ 를 $100 \mathrm{ng} / \mathrm{mL}$ 의 농도가 되도록 처리한 뒤 taxifolin을 각 농도 별로 처리하였다. 18 시간 후 세포배양액을 수거하여 cytokine측정에 이용하였다. 배양액을 cytokine으로 coating된 
96-well plate에 $50 \mu \mathrm{L}$ 를 첨가하고 $4^{\circ} \mathrm{C}$ 에서 overnight 반응시켰 다. Washing buffer를 이용하여 3회 세척한 후 $100 \mu \mathrm{L}$ 의 Biotinylated antigen-affinity reagent를 각각의 well에 첨가한 후 1 시간 동안 상온에서 반응시켰다. 다시 washing buffer를 이용 하여 3회 세척 후 $100 \mu \mathrm{L}$ 의 Streptavidin-HRP conjugate reagent 를 각각의 well에 첨가하고 1 시간 동안 상온에서 반응시켰다. 반응이 끝난 well을 washing buffer로 3회 세척 후 3,3,5,5Tetramethylbenzidine substrate를 $100 \mu \mathrm{L}$ 씩 처리하여 20분간 반 응시킨 후 $100 \mu \mathrm{L}$ 의 stop solution 처리하여 반응을 정지시켰다. 이 용액을 ELISA reader (Benchmark PLUS, Bio-Rad)로 450 $\mathrm{nm}$ 에서 흡광도를 측정하였다.

NO assay. NO의 농도는 배양액내의 nitrite 농도를 Griess reagent system을 이용하여 측정하였다(McCartney-Francis 등, 1999). 배양된 RAW 264.7세포에 LPS를 $100 \mathrm{ng} / \mathrm{mL}$ 의 농도가 되도록 처리하고 4시간 배양한 후 추출된 taxifolin을 각 농도 별로 처리 하였다. 18 시간 배양 후 배양액의 $100 \mu \mathrm{L}$ 와 동일한 Griess reagent를 넣어주고 10 분간 상온에서 반응시킨 후 ELISA reader로 $540 \mathrm{~nm}$ 에서 흡광도를 측정하였다. Sodium nitrite의 농도 별 표준곡선을 이용하여 배양액내의 NO 농도를 결정하였다.

Western blot analysis. 전기영동을 위한 단백질 시료의 추출은 처리시간 별로 세포를 ice-cold PBS로 3회 세척 후, RIPA buffer를 넣어 $4^{\circ} \mathrm{C}$ 에서 30 분간 반응시키고, $15,000 \mathrm{rpm}$ 에서 15 분간 원심분리한 후 상층액을 수거하였다. 동일한 양의 단백질 을 sodium dodecyl sulfate polyacrylamide gel electrophoresis 로 분리시킨 후 단백질을 nitrocellulose membrane에 transfer 하였다. Membrane을 항체의 비특이적결합을 차단하기 위하여 blocking solution (5\% skim milk in PBS-T buffer)에서 2시 간 동안 상온에서 반응시켰다. 반응이 끝난 membrane에 $\mathrm{COX}$ 2 primary antibody 를 $1: 1,000$ 의 비율로 희석하여 처리한 후 4 에서 overnight 반응하였다. $0.1 \%$ tween 20 을 함유한 PBS-T 용액으로 10 분씩 5 회 세척 후 secondary antibody로 반응시켰 다. 이어서 ECL detection kit (Pierce Biotechnology, USA) 으로 반응시킨 후 X-ray film 상에서 단백질을 확인하였다. 각 시료의 단백질정량은 BCA protein assay kit (Intron, Korea)를 사용하여 정량하였다.

통계처리 및 분석방법. 통계처리는 SPSS 10.0 을 이용하였다. 대 조군과 실험군간의 결과는 mean $\pm \mathrm{SD}$ 로 나타냈으며 $t$-test로 통 계처리의 유의성을 검정하였다.

\section{결 과}

천년초의 항산화활성. 천년초는 잎과 열매의 형태로 구분되어 있으며 각각의 항산화 활성을 측정하였다(Fig. 1). 항산화활성은 $\mathrm{IC}_{50}$ 값으로 나타내었다. 대조군으로 사용된 ascorbic acid의 경 우 $54.69 \pm 1.37 \mu \mathrm{g} / \mathrm{mL}$ 로 측정 되었으며 천년초의 열매와 잎추출 물의 항산화활성은 $40.23 \pm 2.21$ 과 $38.33 \pm 1.07 \mu \mathrm{g} / \mathrm{mL}$ 로 측정되었 으며 이는 대조군 보다도 더욱 높은 효과를 보였다.

Taxifolin의 추출. 천년초 $50 \mathrm{~g}$ 에서 추출한 조추출물을 이용하여 taxifolin을 HPLC를 이용하여 순수분리 하였다. 분리조건은 Table 1에 표시하였다. Taxifolin 표준품과 동일한 시간대에서 천 년초 잎추출물의 분획을 분리하였고(Fig. $2 \mathrm{~A}, \mathrm{~B}$ ), 표준용액과 천 년초 추출물의 동일한 시간대의 PDA spectrum을 측정하였을

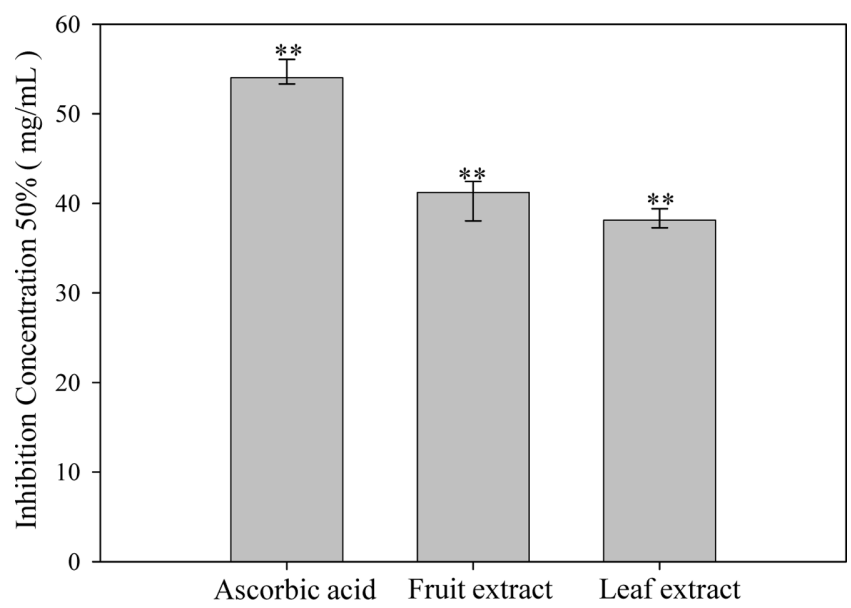

Fig. 1 Anti-oxidative activity of methanol extracts from different parts of Opuntia humifusa. Ascorbic acid was used as a positive control. $\mathrm{IC}_{50}$ value represent the $50 \%$ inhibition concentration. Data points and bar represent arithmetic mean $\pm \mathrm{SD} \quad(n=3)$. $* * p<0.001, \quad * p<0.05$ as compared to the untreated group (control).

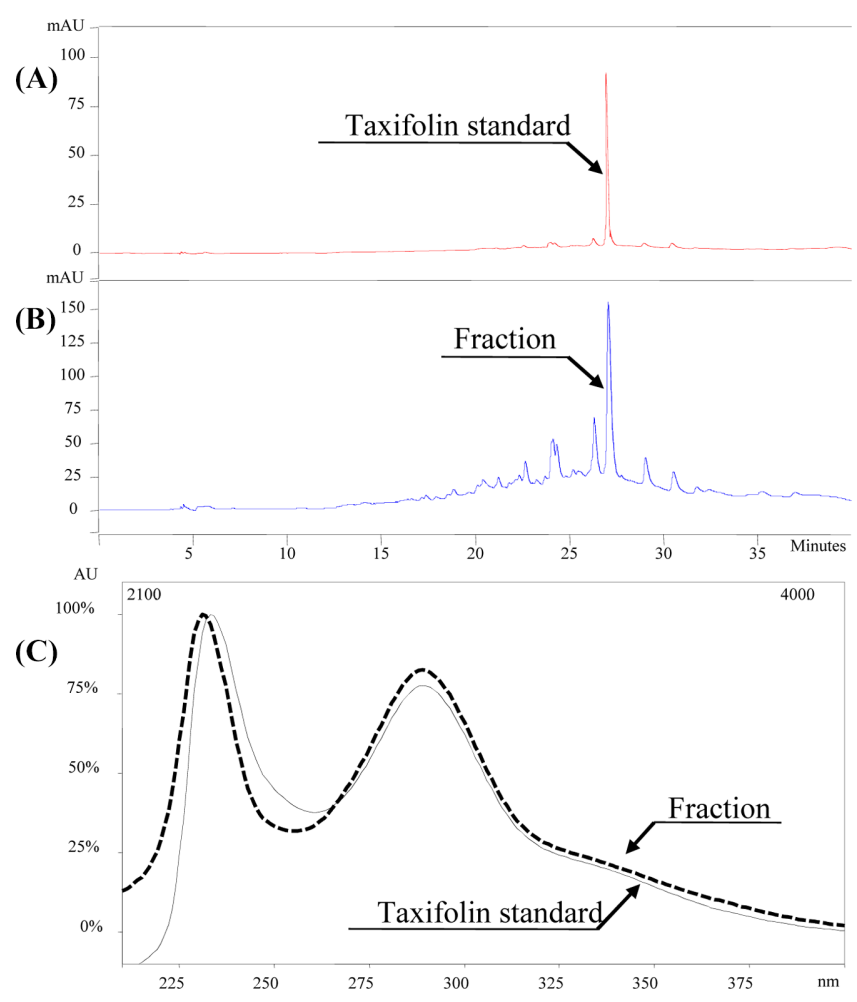

Fig. 2 Analysis and preparation of Opuntia humifusa crude extract and standard taxifolin using HPLC. (A): Standard taxifolin, (B): Opuntia humifusa crude extract, (C): PDA spectrum of taxifoilin standard and fraction.

때 거의 동일한 패턴의 spectrum (Fig. 2C)을 나타내었다. 이러 한 방법으로 천년초 건조분말 $50 \mathrm{~g}$ 에서 $26.17 \mathrm{mg}$ 의 taxifolin을 회수하였다.

세포독성. 마우스의 대식세포인 RAW 264.7 세포에 대한 taxifolin이 자극을 일으키지 않는 농도를 확인하기 위하여 MTT assay를 실행하였다. MTT assay는 생존세포의 미토콘드리아의 


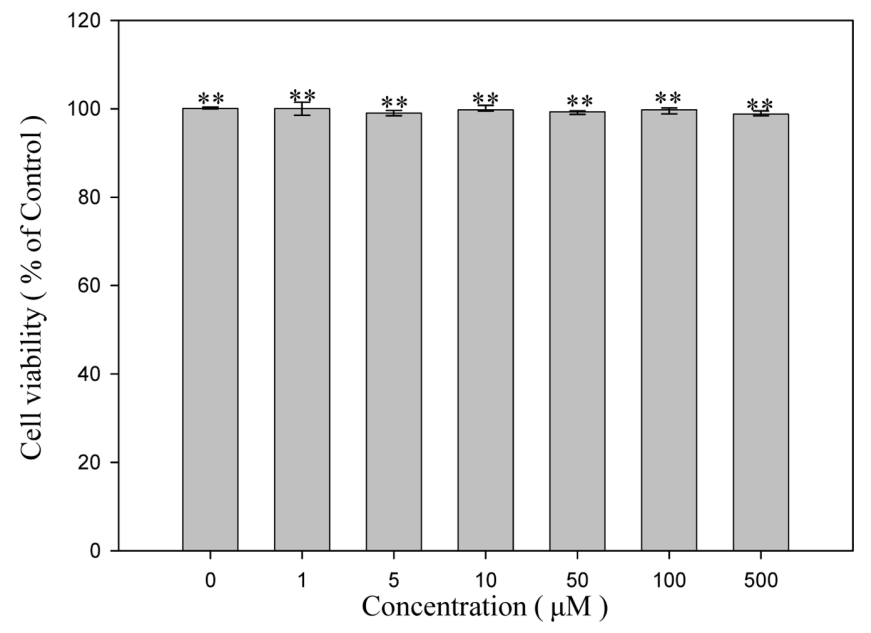

Fig. 3 Cell viability of taxifolin in RAW 264.7 cells. Raw 264.7 cells were treated with various concentrations $(1-500 \mu \mathrm{M})$ of taxifolin. Cell viability was measured by MTT assay. Data points and bar represent arithmetic mean $\pm \mathrm{SD}(n=3) .{ }^{* *} p<0.001,{ }^{*} p<0.05$ as compared to the untreated group (control).

능력을 이용하는 검사법으로 탈수효소작용에 의하여 노란색의 수용성기질이 청자색을 띄는 비수용성 MTT formazan결정체로 환원된다(Kim 과 Park, 2007). 이러한 특성을 이용하여 24시간 동안 처리한 결과 taxifolin은 $500 \mu \mathrm{M}$ 농도에서 $1.2 \%$ 가량 감 소되었지만 매우 적은 수치로 이후 측정 결과에는 영향을 주지 않았다(Fig. 3). 따라서 이후의 실험은 세포성장률에 영향을 주 지 않는 $500 \mu \mathrm{M}$ 농도까지 진행하였다. taxifolin의 항염증효과 는 세포생존율의 감소가 아니라 taxifolin의 효과임을 확인할 수 있었다.

Cytokine assay. 염증반응의 지표인 염증성 사이토카인의 생성 을 확인하기 위하여 LPS로 염증반응을 유도한 RAW 264.7 cell에서 ELISA 법을 이용하여 측정하였다(Fig. 4). RAW 264.7 cell만 배양한 무처리군에서는 IL-6 생성량은 $5.89 \pm 0.08 \mathrm{pg} / \mathrm{mL}$ 농도로 매우 낮게 측정된 반면, LPS 처리 후에는 $4014.78 \pm 5.73$ $\mathrm{pg} / \mathrm{mL}$ 그 양이 현저히 증가하였다. 이 처리구에 taxifolin을 100, $500 \mu \mathrm{M}$ 을 처리하였을 때 각각 $2514.28 \pm 4.33,2139.75 \pm 1.64$ $\mathrm{pg} / \mathrm{mL}$ 로 IL-6의 양이 감소되었다. TNF- $\alpha$ 의 생성량은 세포만 배양한 무처리군에서는 $0.99 \pm 1.74 \mathrm{pg} / \mathrm{mL}$ 로 매우 낮게 측정된 반 면, LPS 처리 후 $1126.31 \pm 45.28 \mathrm{pg} / \mathrm{mL}$ 로 매우 높게 측정되었 다. LPS 처리구에 taxifolin을 $100,500 \mu \mathrm{M}$ 을 처리하였을 때 각각 $1078.89 \pm 31.41,1063.04 \pm 34.71 \mathrm{pg} / \mathrm{mL}$ 로 소폭 감소되어 측 정되었다.

No production. 활성산소종인 $\mathrm{NO}$ 는 주로 대식세포에서 Larginine으로부터 iNOS (inducible nitric oxide synthase) 에서 의해 합성되는 작은 분자량의 자유라디칼로서 염증반응 발생의 대표적인 인자이다. 따라서 No production의 저해효과를 확인하 기 위하여 RAW 264.7세포에 염증유발에 주로 사용되는 LPS 를 $1 \mu \mathrm{g} / \mathrm{mL}$ 의 농도가 되도록 처리하고 4시간 배양한 후 추출 된 taxifolin을 각 농도별로 처리하였다. 18시간 동안 배양한 후 배양액내의 $\mathrm{NO}$ 의 양을 측정하였다(Fig. 5). 그 결과 LPS 처리 구 $(40.38 \pm 0.91 \mu \mathrm{M})$ 에 비하여 taxifolin $50 \mu \mathrm{M}$ 처리구 $(27.88 \pm$ $0.15 \mu \mathrm{M}$ )에선 유의적인 효과를 보여주었으며 $500 \mu \mathrm{M}$ 처리구 $(17.43 \pm 0.27 \mu \mathrm{M})$ 에서는 $\mathrm{NO}$ 의 양이 $50 \%$ 이상 줄어드는 것을 확
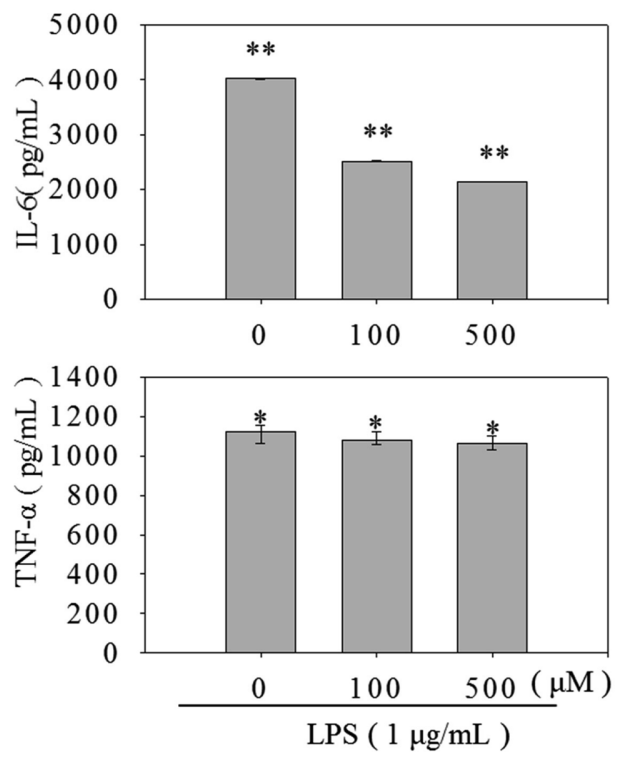

Fig. 4 Inhibitory effect of taxifolin on LPS-induced production of inflammatory cytokines from RAW 264.7 cells. Cell $\left(1 \times 10^{5}\right.$ cells/well $)$ were incubated with taxifolin $(100,500 \mu \mathrm{M})$ in the presence of LPS (1 $\mu \mathrm{g} / \mathrm{mL}$ ). Cytokine production was determined in supernatant by enzyme immunoassay. Data points and bar represent arithmetic mean $\pm \mathrm{SD}$ $(n=3) . * * p<0.001, * p<0.05$ as compared to the untreated group (control).

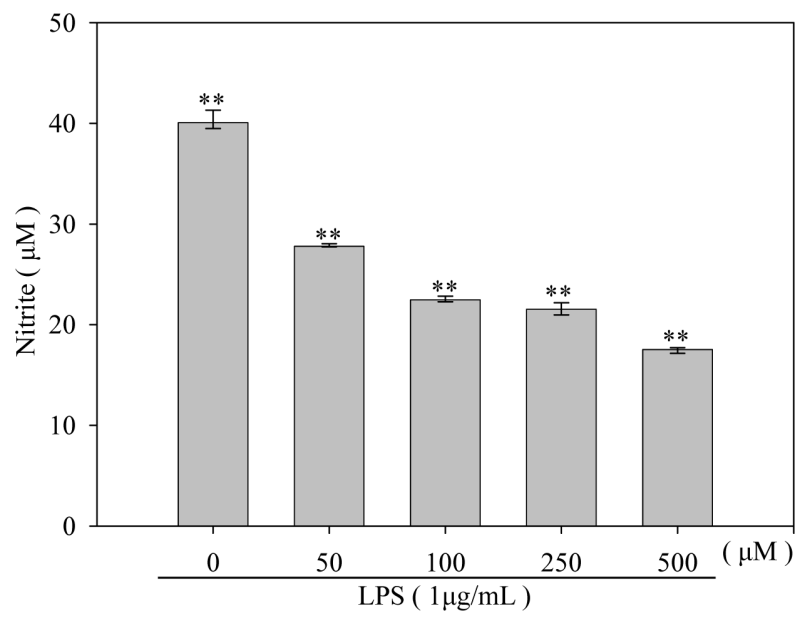

Fig. 5 Inhibitory effect of taxifolin on LPS-induced production of NO from RAW 264.7 cells. Cell $\left(1 \times 10^{5}\right.$ cells/well $)$ were incubated with taxifolin $(100,500 \mu \mathrm{M})$ in the presence of LPS $(1 \mu \mathrm{g} / \mathrm{mL})$. NO production was determined in supernatant by Griess reagent. Data points and bar represent arithmetic mean $\pm \mathrm{SD}(n=3) .{ }^{* *} p<0.001,{ }^{*} p<0.05$ as compared to the untreated group (control).

인할 수 있었다. 또한 $\mathrm{NO}$ 의 양은 taxifolin의 농도의존적으로 감소하였다.

COX-2 단백질발현. 염증성 물질인 $\mathrm{PGE}_{2}$ 를 합성하는 $\mathrm{COX}-2$ 에 대한 taxifolin의 저해능을 확인하기 위하여 LPS를 $1 \mu \mathrm{g} / \mathrm{mL}$ 의 농도가 되도록 처리하고 4시간 배양한 후 추출된 taxifolin을 각 농도별로 처리하였다. 18시간을 배양하여 Western blot을 통해 COX-2 단백질의 발현량을 확인하였다. 그 결과 LPS로 유도된 


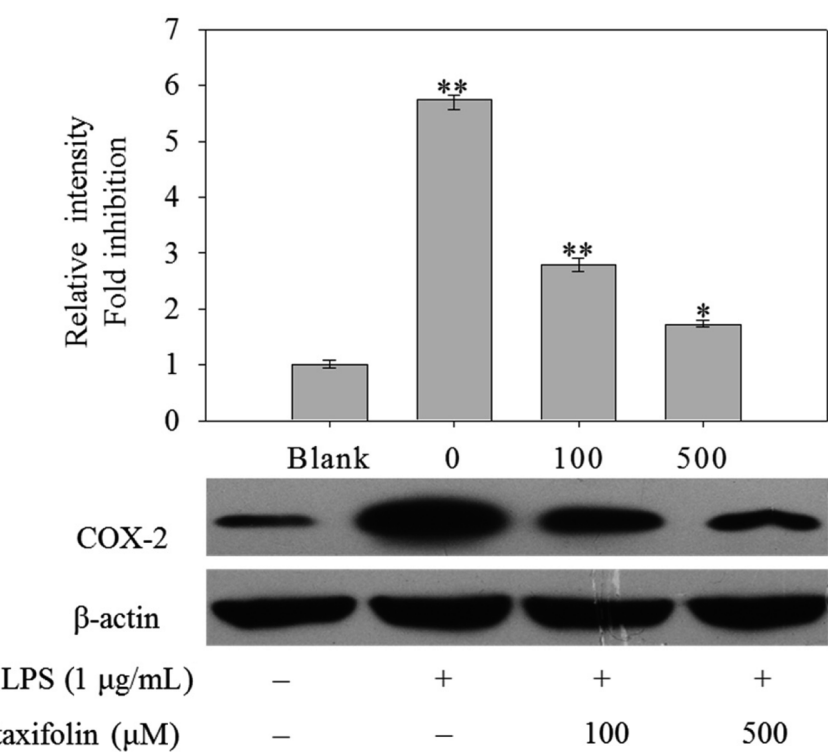

Fig. 6 Inhibition of LPS-induced COX-2 expression by taxifolin on RAW 264.7cells. Cell $\left(1 \times 10^{5}\right.$ cells/well $)$ were incubated with taxifolin $(100,500 \mu \mathrm{M})$ in the presence of LPS $(1 \mu \mathrm{g} / \mathrm{mL})$. Cell lysate $(15 \mu \mathrm{g})$ of COX-2 protein expression were determined by western blot. Data points and bar represent arithmetic mean $\pm \mathrm{SD}(n=3)$. $* * p<0.001,{ }^{*} p<0.05$ as compared to the untreated group (control).

COX-2의 발현량에 비하여 taxifolin을 $500 \mu \mathrm{M}$ 처리하였을 때 약 $66 \%$ 이상 감소되는 것을 확인할 수 있었다.

\section{고 찰}

한국에서 자생하는 천년초(Opuntia humifusa)는 'Opuntia'속으 로 내륙에서 월동이 가능해 척박한 환경에서도 경작이 가능한 다년생식물이다(Kim, 2007). 그리고 천년초에는 부위에 따라 다 양한 무기질과 아미노산 뿐만 아니라 oleic acid과 같은 불포화 지방산 등 영양소를 골고루 함유하고 있어(Shin, 2011) 고혈압, 당뇨, 관절염, 위염 등 다양한 생리활성이 있는 것으로 알려져 있다. 이러한 천년초의 성분 중 강력한 항산화 활성을 보이는 taxifolin이 존재하는 것으로 보고 되었다(Lee 등, 2010). 또한 taxifolin의 항산화 효과가 $\alpha$-tocopherol보다 우수하다고 보고하 였으며(Lee, 2004), 본 연구에서는 천년초의 taxifolin을 분리하 고 항염증 효과를 확인하였다.

대식세포는 면역반응에서 중요한 역할을 하며 $\mathrm{NO}$, prostaglandins (PGs) 그리고 pro-inflammatory cytokines을 포함한 염증성인자 의 발현을 조절한다(Iontcheva 등, 2004). 활성산소종인 $\mathrm{NO}$ 는 주로 대식세포에서 L-arginine으로부터 iNOS에 의해 합성되는 자유라디칼 물질로서 외부 세균의 침입으로부터 방어하거나 항 암작용 또는 독성에 관여하는 전달자로, 과량의 $\mathrm{NO}$ 형성은 염 증반응을 유도하여 조직의 침윤, 신경손상 등을 유발한다(Stuehr 등, 1991; McCartney Francis 등, 1993). 강한 항산화 활성을 갖는 천년초의 추출물인 taxifolin에서 LPS에 의해 염증반응이 유도된 RAW 264.7 세포는 $\mathrm{NO}$ 의 생성을 저해함을 확인하였다. 또한 iNOS의 발현억제는 NO 발현억제와 유사한 경향을 나타 냄으로 taxifolin에 의한 $\mathrm{NO}$ 형성억제는 $\mathrm{iNOS}$ 의 발현저해를 경
유한 것임을 간접적으로 알 수 있었다.

기존의 항염증 약물들의 작용기전은 prostaglandin 합성을 억 제하며 이는 COX-2의 생성 및 효소활성 저해에 의한 것이다. $\mathrm{COX}$ 는 $\mathrm{COX}-1$ 과 $\mathrm{COX}-2$ 로 구분되는데, 특히 COX-2는 동물이 나 인간의 염증반응 부위에서 발현된다(Masferrer 등, 1994). 따 라서 COX-2에 의한 prostaglandin의 합성은 급성염증반응을 매 개하는 것으로 여겨지고 있다(Lee 등, 2011). Western blot을 이용하여 $\mathrm{COX}-2$ 단백질의 발현을 분석한 결과 taxifolin에 의해 형성되는 $\mathrm{COX}-2$ 를 $500 \mu \mathrm{M}$ 에서 약 $66 \%$ 이상 감소시켰다.

염증반응의 매개물질인 Cytokine 중 IL-6, TNF- $\alpha$ 는 proinflammatory cytokine으로서 여러 면역반응과 연관 되어있다. LPS 반응의 주요 매개체로서 만성염증과 내제면역에 관여하는 $\mathrm{TNF}-\alpha$ 는 주로 대식세포와 비만세포에서 분비되며(Lee 등, 2003) 염증성 병변에서만 발생하는 IL-6는 림프구를 활성화시킴으로 써 항체생산을 증가시킨다(Delgado 등, 2003). 본 연구에서는 RAW 264.7 세포에서 LPS로 염증반응을 유도하였고 taxifolin 을 $100,500 \mu \mathrm{M}$ 처리하였다. 특히 IL-6의 발현량은 대조군 대 비 $47 \%$ 까지 감소 하였지만 $\mathrm{TNF}-\alpha$ 의 발현량은 큰 변화를 보이 지는 않았다. LPS가 대식세포의 염증반응을 유도하여 발현된 cytokine 중 IL-6의 발현을 유의성 있게 억제하였다.

기존의 손바닥 선인장을 이용한 항산화 효과 및 면역계를 활 성화시키는 효과 등이 최근 연구에 의해서 밝혀지고 있다(Kwon 과 Song, 2005). 본 실험은 기존의 손바닥 선인장의 한 종류인 천년초 추출물 성분 중 taxifolin을 단리하여 LPS에 의해 염증 반응이 유도된 RAW 264.7세포에서 면역관련 인자인 COX-2 단백질과 pro-inflammatory cytokine인 TNF- $\alpha$ 및 IL-6의 발현 을 유의성 있게 저해하였다. 이 결과를 토대로 천년초의 taxifolin 은 염증성 질환의 예방과 치료에 효과적으로 사용할 수 있을 것으로 기대된다.

\section{초 록}

본 연구는 항산화 효과가 뛰어난 천년초를 이용하여 taxifolin을 순수분리하고 항염증 효과를 연구하였다. 천년초는 잎과 열매로 나누어 추출하였고 추출공정으로는 먼저 메탄올을 이용하여 조 추출물을 추출하였다. 이렇게 얻어진 조추출물의 항산화 효과를 측정하였는데. 잎 추출물에서 $38.33 \pm 1.07 \mu \mathrm{g} / \mathrm{mL}$ 로 높은 항산화 활성을 나타내었다. high performance liquid chromatography를 이용하여 taxifolin을 분리하고 확인하였다. 이렇게 얻어진 taxifolin을 이용하여 항염증 효과를 측정하였다. Taxifolin의 농 도별 세포독성 측정에서는 $500 \mu \mathrm{M}$ 농도까지 처리 하였을 때 특별한 세포독성을 나타내지는 않았다. lipopolysaccharide에 의 해 유도된 RAW 264.7 cell을 이용한 taxifolin의 염증성 cytokine 측정실험에서는 IL-6의 발현양을 $500 \mu \mathrm{M}$ 처리시 $2139.75 \pm 1.64$ $\mathrm{pg} / \mathrm{mL}$ 로 대조군에 비하여 $47 \%$ 까지 저해하였다. 하지만 TNF$\alpha$ 의 발현량은 대조군에 비하여 $5 \%$ 만 감소하였다. 염증성지표의 $\mathrm{NO}$ 의 생성량은 $500 \mu \mathrm{M}$ 처리시 $17.43 \pm 0.27 \mu \mathrm{M}$ 로 대조군에 비 하여 $57 \%$ 까지 감소 시켰으며, 이와 관련된 COX-2 단백질의 발현양은 약 $66 \%$ 이상 감소시켰다. 따라서 천년초에서 추출한 taxifolin은 항염증 효과가 있음을 확인할 수 있다.

Keywords anti-inflammatory $\cdot$ cyclooxygenase- $2 \cdot$ cytotoxicity $\cdot$ interleukin-6 $\cdot$ Opuntia humifusa $\cdot$ taxifolin 
감사의 글 본 연구는 보건복지부 보건의료연구 개발사업지원에 의하여 이 루어진 것임(과제번호: $\mathrm{HN} 14 \mathrm{C} 0085$ ).

\section{References}

Atreya R and Neurath MF (2005) Involvement of IL-6 in the pathogenesis of inflammatory bowel disease and colon cancer. Clin Rev Allerg Immu 28, 187-96.

Blois MS (1958) Antioxidant determination by the use of a stable free radical. Nature 25, 1199-200.

Carmen S (2000) Processing technologies: An alternative for cactus pear (Opuntia spp) fruits and cladodes. J Aari Environ 46, 209-25.

Delgado AV, McManus AT, and Chambers JP (2003) Production of tumor necrosis factor-alpha, interleukin 1-beta, interleukin 2, and interleukin 6 by rat leukocyte subpopulations after exposure to substance P. Neuropeptides 37, 355-61.

Iontcheva I, Amar S, Zawawi KH, Kantarci A, and Van Dyke TE (2004) Role for moesin in lipopolysaccharide stimulated signal transduction. Infect Immun 72, 2312-20.

Kim DJ, Jung JH, Kim SG, Lee HG, Lee SK, Hong HD et al. (2011) Antioxidants and anti-obesity activities of hot water and ethanolic extracts from Cheonnyuncho (Opuntia humifusa). Korean J Food Preserv 18, 366-73.

Kim JY and Park YS (2007) A study of application for cosmeceutical of Fagopyrum esculentum extracts. J Soc Cosmet Sci Korea 34, 83-92.

Kim MG (2007) Physicochemical characteristics of jeung-pyun by different addition ratios of prickly pear powder during storage. MS Thesis. SungShin University, Korea.

Kwon DK and Song YJ (2005) Effect of Opuntia humifusa supplementation on endurance exercise performance in rats fed a high-fat diet. Korean $J$ Exercise Nutr 9, 183-8.

Lee AK, Sung SH, Kim YC, and Kim SG (2003) Inhibition of lipopolysaccharide-inducible nitric oxide synthase, TNF- $\alpha$ and COX-2 expression by sauchinone effects on I- $\mathrm{KB} \alpha$ phosphorylation, C/EBP and AP-1 activation. British J Pharmacol 139, 11-20.

Lee KH, Cho YL, Joo CG, Joo YJ, Kwon SS, and Park C (2011) Study on the anti-inflammatory effect of kaempferol and kaempferol rhamnosides isolated from Hibiscus cannabinus L. Korean J Medicinal Crop Science 19, 426-34.

Lee KS (2004) Antioxidant, antimicrobial effect of the extracts of cactus Cheonnyuncho (Opuntia humifusa) and identification of activity substance. MS Thesis Hoseo University, Korea.

Lee KS and Lee KY (2010) Biological activity of phenolic compound from a Cactus Cheonnyuncho (Opuntia humifusa) in Korea. J Korean Soc Food Sci Nutr 39, 1132-6.

Lee LS, Oh CS, and Lee KY (2005) Antioxidative Effect of the Fractions Extracted from a cactus Cheonnyuncho (Opuntia humifusa). Korean J Food SCI TECHNOL 37. 474-8.

Lee NH, Yoon JS, Lee BH, Choi BW, and Park KH (2000) Screening of the radical scavenging effects, tyrosinase inhibition and anti-allergic activities using Opuntia ficusindica. Korean J Pharmacognosy 31, 412-5.

Libby P (2006) Inflammation and cardiovascular disease mechanisms. Am J Clin Nutr 83, 456S-60S.

Masferrer J, Zweifel BS, Manning PT, Hauser SD, Leahy KM, Smith WG et al. (1994) Selective inhibition of inducible cyclooxygenase 2 in vivo is antiinflammatory and nonulcerogenic. PNAS 91, 3228-32.

McCartney-Francis N, Allen JB, Mizel DE, Albina JE, Xie QW, Nathan CF et al. (1993) Suppression of arthritis by an inhibitor of nitric oxide synthase. $J$ Exp Med 178, 749-54.

Salerno L, Sorrenti V, Di Giacomo C, Romeo G, and Siracusa MA (2002) Progress in the development of selective nitric oxide synthase (NOS) inhibitors. Curr Pharm Design 8, 177-200.

Shin TS (2011) Food components of different parts of cheonnyuncho (Opuntia humifusa) harvested from Yeosu, Jeonnam in Korea. J Korean Soc Food Sci Nutr 40, 1271-8.

Stuehr HJ, Kwon NS, Weise M, and Nathan C (1991) Purification of the cytokine-induced macrophage nitric oxide synthase: An FAD and FMN containing flavoprotein. PNAS 88, 7773-7.

Yoon JA and Son YS (2009) Effects of Opuntia ficusindica complexes B (OCB) on blood glucose and lipid metabolism in streptozotocin-induced diabetic rats. Korean J Food and Nutr 22, 48-56.

Zamora R, Vodovtz Y, and Billiar TR (2000) Inducible nitric oxide synthase and inflammatory diseases. Mol Med 6, 347-73. 